Borneo Journal of Sciences and Technology, Volume (2), Issue (1), Pages: 13-18

DOI: https://doi.org/10.35370/bjost.2020.2.1-04

e-ISSN: $2672-7439$

(C) 2018, UCTS Publisher.

Submitted: $6^{\text {th }}$ May $2019 \quad$ Accepted: $10^{\text {th }}$ October $2019 \quad$ Published: $31^{\text {th }}$ January 2020

\title{
Flexural Behaviour of Reinforced Concrete Beam Embedded with Different Alignment of Polystyrene
}

\author{
Danson Tan Tzet Lung, Ling Jen Hua \\ School of Engineering and Technology, University College of Technology Sarawak, 96000 Sibu, \\ Sarawak, Malaysia
}

\begin{abstract}
This study investigates the flexural behaviour of reinforced concrete beam embedded with different alignments of polystyrene blocks. Understanding of its behavior would improve beam by maximising reduction of dead load due to concrete volume. Three beams of dimension $1600 \mathrm{~mm}$ x $175 \mathrm{~mm}$ x $300 \mathrm{~mm}$ were tested under the four-point load setup. These specimen had three different alignments of polystyrene block located below the neutral axis. The first specimen with a singular rectangle polystyrene block was used as a reference specimen to investigate the presence of spacing between the polystyrene blocks, and the presence of a mid-span spacing with concrete strut at the sides of the beam. The beams failed due to crushing of concrete at the top with major flexural cracks. The result from the test showed the effects of the alignments of the polystyrene blocks on the beam. The presence of spacings decreases the ultimate capacity per unit volume while increases its ductility. The presence of mid-span spacing and concrete struts improves the ultimate capacity per unit volume but decreases its ductility. Further studies may involve width of the spacings and layout of polystyrene blocks.
\end{abstract}

Keywords: Flexural Behavior, Reinforced Concrete Beam, Static Load Test, Polystyrene, Concrete Reduction

\section{INTRODUCTION}

Concrete contributes to a large portions of reinforced concrete (RC) structures. It imposes a considerable dead load to the structure. Studies shown that it is possible to develop RC members with voids without affecting its strength [2]. Therefore, voided concrete members may be used as an improved RC member. However, the behaviour of voided members are still unclear, especially in voided beam members which brings the need for further studies.

Table 1 shows various studies of voided slabs and beams. Various type of materials were used as void formers such as plastic balls, styrofoams and polyvinyl chloride (PVC) pipes. Generally, the reduction of concrete volume in slab specimen were up to approximately $30 \%$ while only losing $5 \%$ to $10 \%$ of their strength. This shows that voided slabs are more effective compared to solid RC slab in term of concrete per unit volume $\left(P_{u} / \mathrm{V}_{\mathrm{c}}\right)$. On the other hand, concrete volume reduction of voided beam specimens were only up to approximately $10 \%$. Although less effective than voided slab, voided beam members were still more effective compared to solid RC beams.

This paper investigates the response of voids in reinforced concrete beams. The voided sections were located below the neutral axis as it is more effective [7]. Polystyrene was used as the void former due to its lightweight properties. An experimental study was conducted to investigate the flexural behavior of the voided beam.

Table 1: Previous studies on voided members

\begin{tabular}{ccccc}
\hline Type & Material & $\begin{array}{c}\mathrm{V}_{\mathrm{c}}, \\
(\%)\end{array}$ & $\begin{array}{c}P_{\mathrm{u}}, \\
(\%)\end{array}$ & Reference \\
\hline Slab & Hollow & 67.2 & 98.8 & {$[1]$} \\
Slab & Plastic Ball & 75.1 & 99.6 & {$[2]$} \\
Slab & Styrofoam & 78.6 & 91.3 & {$[3]$} \\
Slab & PVC Pipe & 76.0 & 69.0 & {$[9]$} \\
Slab & Hollow & 72.0 & 99.0 & {$[1]$} \\
Beam & Polystyrene & 88.2 & 97.4 & {$[5]$} \\
Beam & Plastic Balls & 94.0 & 97.4 & {$[8]$} \\
Beam & PVC Pipe & 96.4 & 96.3 & {$[4]$} \\
Beam & Plastic Bottle & 98.0 & 97.0 & {$[7]$} \\
\hline
\end{tabular}

Note: Comparative to Solid Slab/Beam, $V_{c}=$ Volume of

Concrete, $P_{\mathrm{u}}=$ Ultimate Capacity.

\section{MATERIALS AND METHODS}

\section{Specimen}

Three RC beams embedded with polystyrene specimen were prepared $(1600 \mathrm{~mm} \times 175 \mathrm{~mm} \times 300 \mathrm{~mm})$. The beams were reinforced with two top bars (2T10), two bottom bars (2T12) and eleven shear links (11R6 - 
$150 \mathrm{~mm}$ spacing) as presented in Figure 1. The nominal yield strength of the top and bottom bars was 500 $\mathrm{N} / \mathrm{mm}^{2}$ while the shear links was $250 \mathrm{~N} / \mathrm{mm}^{2}$. Concrete cover of $25 \mathrm{~mm}$ was provided at all sides.
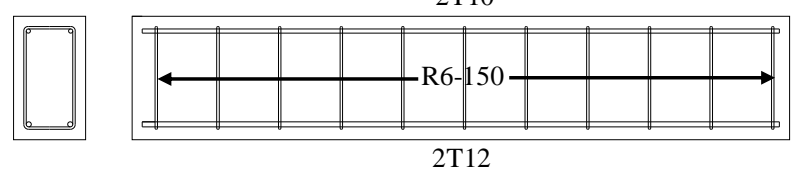

Figure 1: Reinforcement details

The specimens were casted using ready-mixed concrete of grade 25 in timber formworks. The casted specimens were than cured for 28 days prior to testing.

All the polystyrene blocks were placed at a distance of $118 \mathrm{~mm}(0.45 d)$ from the top of the beam (Figure 2(a)). Figure 2 illustrates the alignments of polystyrenes in beams, which includes (a) cross-section view of all specimens, (b) a singular rectangular polystyrene block (PB1), (c) eight rectangular polystyrene blocks with seven spacings, $S_{y}$ of $25 \mathrm{~mm}$ (PB2) and (c) two trapezoidal polystyrene blocks with a $50 \mathrm{~mm}$ spacing at the centre of the beam (PB3) (Table 4). PB1 was used as the reference specimen to investigate the effects of (a) the presence of spacings between the polystyrene blocks and (b) the presence of a mid-span spacing and concrete strut at the sides.

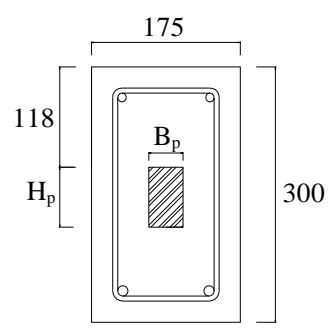

(a) Cross section view of all specimen

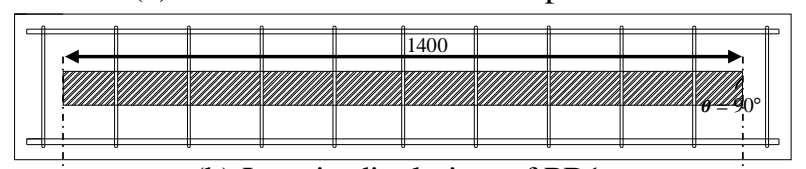

(b) Longitudinal view of PB1

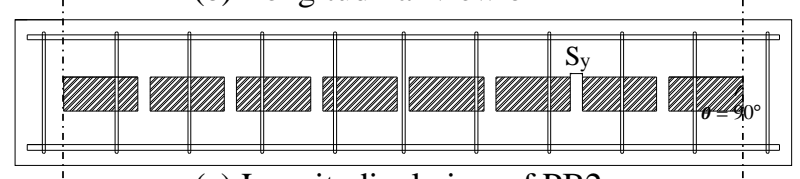

(c) Longitudinal view of PB2

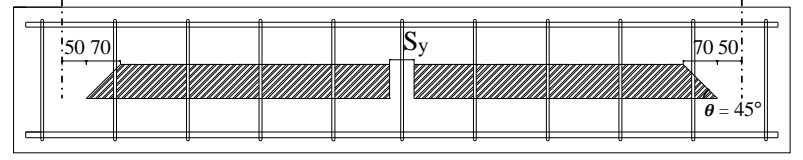

(d) Longitudinal view of PB3

Note: All dimensions are in $\mathrm{mm}$.

Figure 2: Alignments of polystyrene
Table 4: Polystyrene details (Refer to Figure 2).

\begin{tabular}{ccccc}
\hline Beam & $B_{p}(\mathrm{~mm})$ & $H_{p}(\mathrm{~mm})$ & $S_{y}(\mathrm{~mm})$ & $\boldsymbol{\theta}\left({ }^{\circ}\right)$ \\
\hline PB1 & & & - & 90 \\
PB2 & 40 & 70 & 25 & 90 \\
PB3 & & & 50 & 45 \\
\hline
\end{tabular}

Note: $B_{p}=$ Width of polystyrene, $H_{p}=$ Height of polystyrene, $S_{y}=$ Length of spacing/concrete ribs, $\boldsymbol{\theta}=$ Corner angle of polystyrene.

\section{Experimental Setup}

The specimens were tested under static loads in a setup of four-point load (Figure 3). The clear span was 1500 $\mathrm{mm}$. The shear span provided, $a_{\mathrm{v}}$ was $620 \mathrm{~mm}$ to induce a greater bending moment in the beam and to avoid the shear plane failure. A hydraulic jack was used to apply load on the specimens. In order to measure the load, a load cell was placed under the hydraulic jack. The displacement of the specimens was measured by three linear variable displacement transducers (LVDT), which was located at the mid-span and below the two point loads. These measuring devices were connected to a data logger for data acquisition.

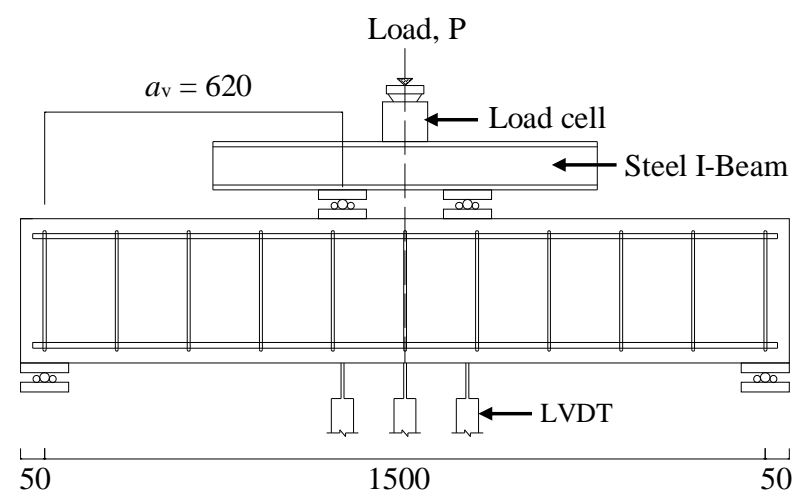

Note: All dimension are in $\mathrm{mm}$.

Figure 3: Experimental setup

\section{Testing Procedure}

First, the condition of the equipment and devices were checked to ensure the quality of testing. The reading were then initialised and the beam was preloaded to approximately $10 \%$ of the estimated ultimate capacity and held for 5 minutes. This step was repeated twice.

The reading were re-initialised to zero before starting the test. The test was started with either an incremental load of $5 \mathrm{kN}$ or an incremental displacement of $0.1 \mathrm{~mm}$, whichever reached first, up to failure of the specimen. The loading was hold at every interval for at least one minute and the crack were monitored throughout the testing. 


\section{RESULTS AND DISCUSSION}

\section{Material Properties}

The properties of concrete and steel used are presented in Tables 2 and 3, respectively. Two concrete cubes of $150 \mathrm{~mm}$ were tested on the testing day of the specimen. The average value was used to represent the strength of the specimen. The compressive strength were close to the grade specified. On the other hand, three samples were tested and the average value represented the yield strength of the steel bar. The yield strengths of the reinforcement bars and shear links were higher than the specified nominal yield strengths of $500 \mathrm{~N} / \mathrm{mm}^{2}$ and $250 \mathrm{~N} / \mathrm{mm}^{2}$ respectively.

Table 2: Concrete strength

\begin{tabular}{ccccc}
\hline \multirow{2}{*}{ Beam } & \multirow{2}{*}{ Sample, $\mathrm{mm}$} & \multicolumn{2}{c}{$f_{\text {cu }}, \mathrm{MPa}$} & \multirow{2}{*}{$f_{\text {cu, avrg, }}$ MPa } \\
\cline { 3 - 4 } & & $\mathrm{C} 1$ & $\mathrm{C} 2$ & \\
\hline PB1 & \multirow{2}{*}{ Cube, 150 } & 24.8 & 25.2 & 25.0 \\
PB2 & 25.9 & 26.5 & 26.2 \\
PB3 & & 25.9 & 26.5 & 26.2 \\
\hline
\end{tabular}

Note: $f_{\text {cu }}=$ Cube strength of concrete.

Table 3: Yield strength of steel bar

\begin{tabular}{ccccc}
\hline \multirow{2}{*}{ Diameter, mm } & \multicolumn{3}{c}{ Yield Strength, $f_{\mathrm{yk}}, \mathrm{MPa}$} & \multirow{2}{*}{$f_{\mathrm{yk}, \text { avrg, }}$ MPa } \\
\cline { 2 - 4 } & $\mathrm{S} 1$ & $\mathrm{~S} 2$ & $\mathrm{~S} 3$ & \\
\hline 10 & 590 & 640 & 635 & 621.7 \\
12 & 531 & 670 & 660 & 620.3 \\
6 & 290 & 279 & 285 & 284.7 \\
\hline
\end{tabular}

Note: $f_{\mathrm{yk}}=$ Yield strength of steel bar.

\section{Crack Pattern}

The crack patterns of all specimens are presented in Figure 4. All specimens demonstrated a similar crack pattern. The first crack occurred in the flexural zone (area between the two point loads), followed by additional cracks which occurred at an offset distance within the flexural zone. These cracks propagated vertically towards the top of the specimen. As the load increased, the progression of these flexural cracks reduced, and shear cracks started to propagate diagonally outside of the flexural zone. These cracks propagated towards the point load. As the beam reaches the yield load, the flexural cracks continued propagating vertically. Towards failure of the specimen, the flexural cracks widen and crushing of the top concrete cover was observed.

All specimens failed due to the crushing of the concrete at the compression zone and had major cracks in the flexural zone (Figure 5). The crushing was relatively minor in $\mathrm{PB} 3$.

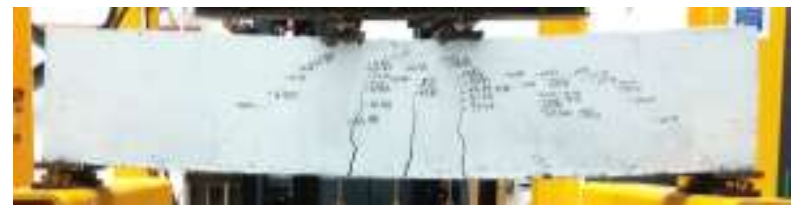

(a) Crack pattern of PB1

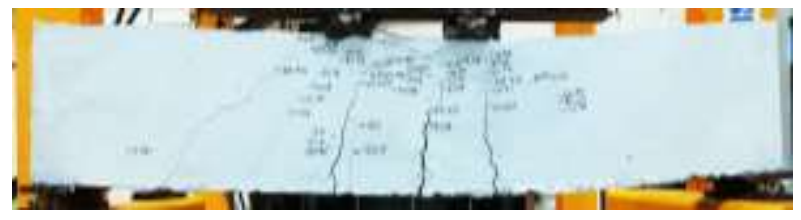

(b) Crack pattern of PB2

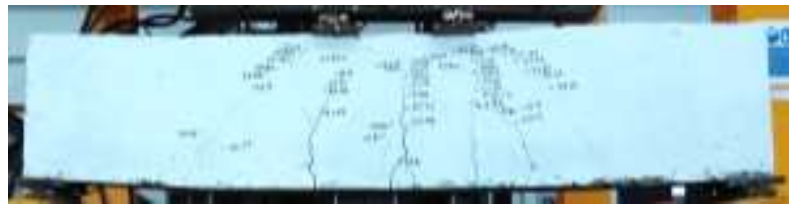

(c) Crack pattern of PB3

Figure 4: Crack pattern of specimens

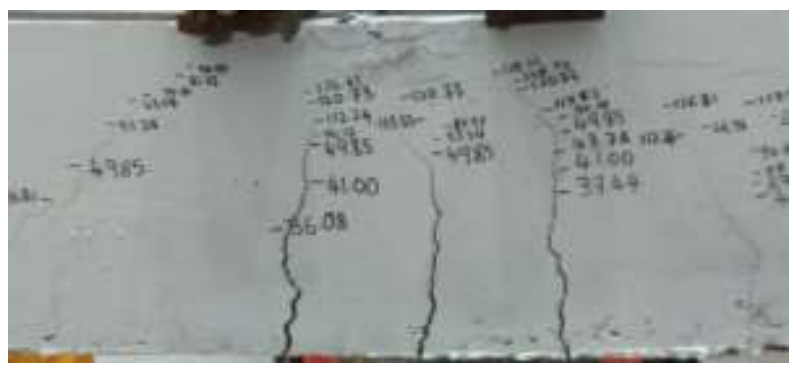

(a) Failure mode of PB1

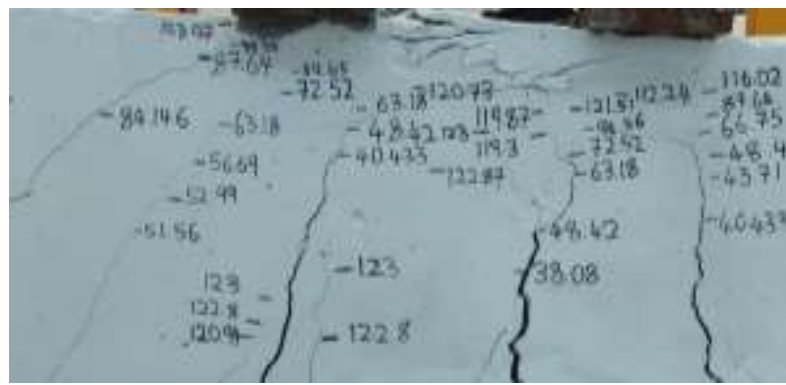

(b) Failure mode of PB2

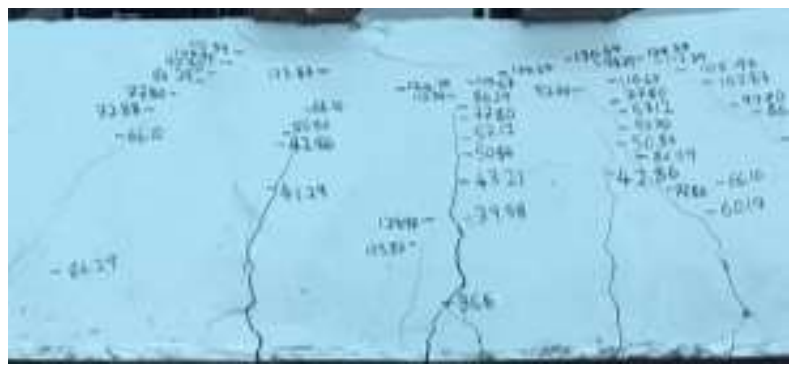

(c) Failure mode of PB3

Figure 5: Failure mode of specimens 
Although the volume reduction in PB1 (4.67\%) was greater than $\mathrm{PB} 2(4.08 \%)$, the cracks in $\mathrm{PB} 2$ were more severe. The spacings between polystyrenes in PB2 may have caused poor workability during casting of the specimen (Figure 7). This may have affected the compaction quality in the region.

The cracks in PB3 were less severe compared to the other specimens. The position and shape of the polystyrene in PB3 seems to have reduced the severity of cracks (Figure 8). The concrete rib which was formed by the spacing between the trapezoidal block at the mid-span may have improved the stress development in the specimen. In addition, the polystyrene blocks in PB3 had an angular edge of $45^{\circ}$ and was located at $50 \mathrm{~mm}$ offset from the support. This created a concrete strut of $45^{\circ}$ which may have reduced the cracks of the specimen.

\section{Load-Displacement Response}

The load-displacement response of the specimens are presented in Figure 6. All specimens started with a high degree of stiffness. Upon occurrence of the first crack $\left(P_{c r}\right)$, their stiffness decreased slightly. As the load increased, the existing cracks widened and propagated further. At the same time, more cracks developed, and the stiffness gradually decreased. A drastic change in stiffness was observed when the specimen started to yield. The displacement increased at a faster rate. At this point, cracks of the specimen were quite severe, approaching the top of the specimen. The width of the flexural cracks widened excessively. Finally, the specimen peaked, reaching its ultimate capacity and loses its ability to resist load.

The first crack, $P_{c r}$ and ultimate load, $P_{u}$ are presented in Table 5. PB2 had the highest first crack loading while PB1 had the lowest. However, PB2 had the lowest yield load as well as ultimate load. PB3 recorded the highest yield load and ultimate load.

Table 5: First Crack load, Yield load and Ultimate load

\begin{tabular}{cccc}
\hline Beam & $\begin{array}{c}P_{c r}, \\
\mathrm{kN}\end{array}$ & $\begin{array}{c}P_{\mathrm{y}}, \\
\mathrm{kN}\end{array}$ & $\begin{array}{c}P_{\mathrm{u}}, \\
\mathrm{kN}\end{array}$ \\
\hline PB1 & 36.08 & 112.24 & 130.64 \\
PB2 & 38.08 & 111.32 & 129.63 \\
PB3 & 36.60 & 115.80 & 133.42 \\
\hline
\end{tabular}

Note: $P_{c r}=$ First crack load, $P_{\mathrm{y}}=$ Yield load, $P_{\mathrm{u}}=$ Ultimate load

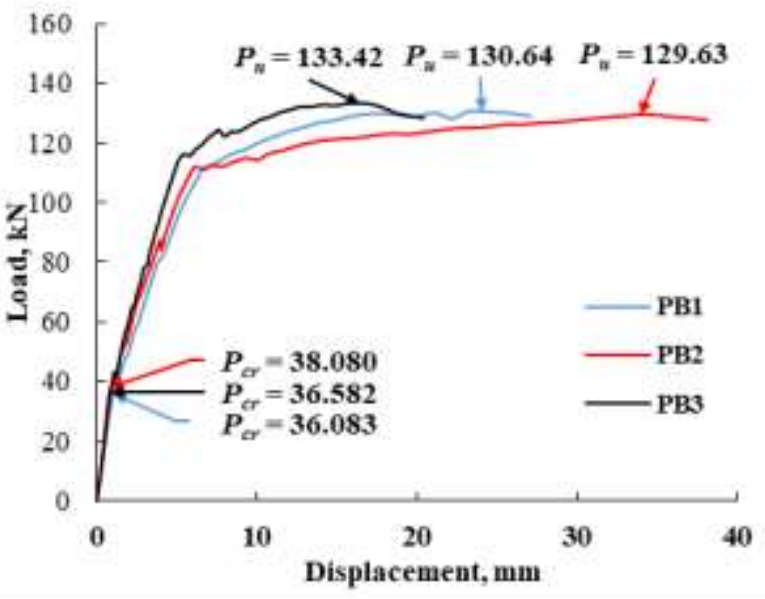

Figure 6: Load-displacement response

\section{Ultimate Load Capacity}

For different sizes of polystyrene, the concrete volume of each specimen varied (Table 6). The ultimate load per unit volume of concrete $\left(P_{u} / \mathrm{V}_{\mathrm{c}}\right)$ was computed to evaluate the performance of the specimens. PB3 showed the highest ultimate capacity as well as $P_{u} / \mathrm{V}_{\mathrm{c}}$. PB2 showed the lowest ultimate capacity and $P_{u} / \mathrm{V}_{\mathrm{c}}$. Due to limited spacings between the polystyrene blocks for aggregate in the concrete to pass through, the quality of compaction was affected (Figure 7).

Table 6: Comparison of Ultimate Load

\begin{tabular}{cccc}
\hline Beam & $\begin{array}{c}P_{u}, \\
\mathrm{kN}\end{array}$ & $\begin{array}{c}\mathrm{V}_{\mathrm{c}}, \\
\mathrm{m}^{3}\end{array}$ & $\begin{array}{c}P_{u} / \mathrm{V}_{\mathrm{c}}, \\
\mathrm{kN} / \mathrm{m}^{3}\end{array}$ \\
\hline PB1 & 130.64 & 0.8008 & 163.14 \\
PB2 & 129.63 & 0.8057 & 160.89 \\
PB3 & 133.42 & 0.8070 & 165.33 \\
\hline
\end{tabular}

Note: $P_{\mathrm{u}}=$ Ultimate load, $\mathrm{V}_{\mathrm{c}}=$ Volume of concrete, $P_{u} / \mathrm{V}_{\mathrm{c}}=$ Ultimate load per unit volume

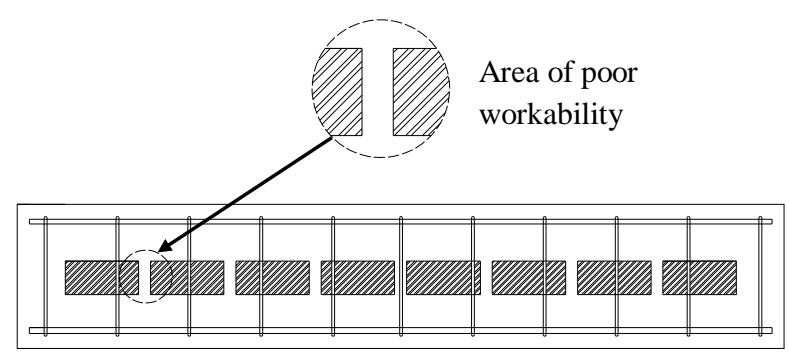

Figure 7: Area of poor workability in PB2

\section{Ductility}

The ductility of the specimens are presented in Table 7. Unlike the behavior observed in the ultimate capacity, the degree of ductility of beams were in a reversed order. PB2 exhibited the most ductile behavior while 
Flexural Behaviour of Reinforced Concrete Beam Embedded with Different Alignment of Polystyrene

PB3 was the stiffest. The concrete ribs in PB2 may have allowed it to become more ductile while the concrete strut in PB3 made it stiffer.

Table 7: Ductile properties of specimen

\begin{tabular}{cccc}
\hline Beam & $\begin{array}{c}\delta_{\mathrm{y}}, \\
\mathrm{mm}\end{array}$ & $\begin{array}{c}\delta_{\mathrm{u}}, \\
\mathrm{mm}\end{array}$ & $\begin{array}{c}\delta_{\mathrm{u}} / \delta_{\mathrm{y}}, \\
\mathrm{mm} / \mathrm{mm}\end{array}$ \\
\hline PB1 & 7.1 & 24.1 & 3.39 \\
PB2 & 6.7 & 34.0 & 5.07 \\
PB3 & 5.7 & 16.5 & 2.89 \\
\hline
\end{tabular}

Note: $\delta_{\mathrm{y}}=$ Yield displacement, $\delta_{\mathrm{u}}=$ Ultimate displacement, $\delta_{\mathrm{u}} / \delta_{\mathrm{y}}=$ Ductility

\section{Effect of Alignment of Polystyrene}

The performance of the specimens with polystyrene of different alignments were compared in reference to PB1, which consisted of a singular block polystyrene.

The presence of spacings showed an increase in the first crack load per unit volume but a decrease in ultimate capacity per unit volume (Table 8). The increase in first crack load per unit volume showed that presence of spacing seems to increase the strength of the specimen prior to cracking. Ideally, the ultimate load per unit volume would increase as well. This could be due to insufficient width of the spacing that led to poor compaction quality. The spacing seems to have increased the ductility of the specimen. The stress of the specimen may have been distributed more evenly through the spacing, allowing the specimen to deform further, and thus, increased the ductility. Improvement can be made by increasing the width of spacing or using the concrete with smaller aggregate size.

The presence of spacing at the mid-span and concrete strut at the side of the beam increased the first crack loading per unit volume and ultimate load per unit volume. However, the ultimate displacement decreased. The mid-span spacing and concrete strut may have acted as an internal member which allowed the concrete to distribute the stress similar to a truss member (Figure 8). It became more rigid, improving the stiffness and ultimate capacity of the member but decreased its ductility. Further studies may be conducted to verify this finding and to improve the design.

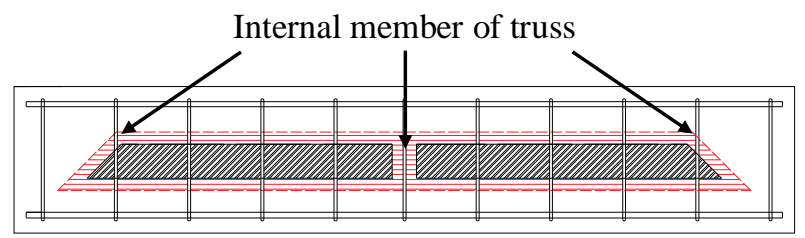

Figure 8: Idealised concrete truss member.
Table 8: Effects of alignments of polystyrene

\begin{tabular}{|c|c|c|c|c|}
\hline $\begin{array}{l}\text { Effect } \\
\text { of: }\end{array}$ & Specimen & $\frac{P_{\mathrm{cr}, \mathrm{i}} / \mathrm{V}_{\mathrm{c}, \mathrm{i}}}{P_{\mathrm{cr}, \mathrm{r}} / \mathrm{V}_{\mathrm{c}, \mathrm{r}}}$ & $\frac{P_{\mathrm{u}, \mathrm{i}} / \mathrm{V}_{\mathrm{c}, \mathrm{i}}}{P_{\mathrm{u}, \mathrm{r}} / \mathrm{V}_{\mathrm{c}, \mathrm{r}}}$ & $\delta_{\mathrm{u}, \mathrm{i}} / \delta_{\mathrm{u}, \mathrm{l}}$ \\
\hline \multirow{2}{*}{$\begin{array}{c}\text { Presence } \\
\text { of } \\
\text { spacing }\end{array}$} & PB1 & 1.00 & 1.00 & 1.00 \\
\hline & PB2 & 1.05 & 0.98 & 1.41 \\
\hline $\begin{array}{l}\text { Presence } \\
\text { of mid - } \\
\text { span }\end{array}$ & PB1 & 1.00 & 1.00 & 1.00 \\
\hline $\begin{array}{l}\text { spacing } \\
\& \text { strut }\end{array}$ & PB2 & 1.01 & 1.01 & 0.68 \\
\hline
\end{tabular}

Note: $P_{\mathrm{cr}, \mathrm{i}} / \mathrm{V}_{\mathrm{c}, \mathrm{i}}$ is the first crack load per unit volume of the specimen, $P_{\mathrm{cr}, \mathrm{r}} / \mathrm{V}_{\mathrm{c}, \mathrm{r}}$ is the ultimate load per unit volume of the reference specimen (PB1), $P_{u, i} / \mathrm{V}_{\mathrm{c}, \mathrm{i}}$ is the ultimate load per unit volume of the specimen, $P_{\mathrm{u}, \mathrm{r}} / \mathrm{V}_{\mathrm{c}, \mathrm{r}}$ is the ultimate load per unit volume of the reference specimen (PB1)

\section{CONCLUSION}

The flexural behavior of reinforced concrete with embedded polystyrene block under static load have been studied. Three different alignments of polystyrene block were tested. The ultimate load capacity per unit volume of concrete were computed to evaluate the efficiency of the specimens. Based on the results, the following conclusions are drawn:

1. All the beams failed due to crushing of the concrete in the compression zone and had major flexural cracks.

2. Different alignments of polystyrene affected the flexural behavior of the beam. Presence of mid-span spacing and concrete strut improves the ultimate load capacity but decreases the ductility of the beam while the effects of spacings between the polystyrene blocks were vice-versa.

3. Further studies or improvements may be done on the width of the spacings and layout of the polystyrene blocks.

\section{ACKNOWLEDGMENT}

This work is supported by the research grant (UCTS/RESEARCH/2/2018/02) of University College of Technology Sarawak. 
Flexural Behaviour of Reinforced Concrete Beam Embedded with Different Alignment of Polystyrene

\section{REFERENCES}

[1] Chung, J.H., Park, J.H., Choi, H.K., Lee, S.C. and Choi, C.S., 2010. An analytical study on the impact of hollow shapes in bi-axial hollow slabs. Fracture Mechanics of Concrete and Concrete Structures, $1729-1736$.

[2] Ibrahim, A.M., Ali, N.K. and Salman, W.D., 2013. Flexural capacities of reinforced concrete two-way bubble deck slabs of plastic spherical voids. Diyala journals of Engineering Sciences, 6(2), 9-20.

[3] Izzat, A.F, Farhan, J.A. and Allawi, N.M., 2014. Behaviour and Strength of One Way Reinforced Concrete Slabs with Cavities. International Conference for Engineering Science, University of Mustansiriyah, Baghdad, Iraq, 100 - 115.

[4] Joy, J. and Rajeev, R. 2014. Effect of Reinforced Concrete Beam with Hollow Neutral Axis. International Journal for Scientific Research \& Development, 2(10), 2321-613.

[5] Manikandan, S., Dharnar, S. and Robertravi, S. 2015. Experimental Study on Flexural Behaviour of Reinforced Concrete Hollow Core Sandwich Beams. International Journal of Advance Research in Science and Engineering, 4(1), 937 946.

[6] Mansur, M.A. and Tan, K.H. (1999). Concrete Beams with Opening: Analysis and Design, CRC Press, Boca Raton.

[7] Mathew, I. and Varghese, S.M. (2016). Experimental Study on Partial Replacement of Concrete in and Below Neutral Axis of Beam. International Journal of Innovative Research in Technology, 3(4), $188-192$.

[8] Sivaneshan, P. and Harishankar, S. (2017). Experimental Study on Voided Reinforced Concrete Beams with Polythene Balls. IOP Conference Series: Earth and Environmental Science, 80(1)

[9] WariyatnoN. G., Haryanto Y., Sudibyo G. H. (2017). Flexural Behavior of Precast Hollow Core Slab Using PVC Pipe and Styrofoam with different Reinforcement, Procedia Engineering, 171, 909-916 